Bull. Fac. Agric., Cairo Univ., 65:255-264 (2014)

\title{
INVESTIGATIONS ON FABA BEANS, Vicia faba $L$. 34. SELECTION METHODS VS. ORIGINAL SEEDS OF VARIETY CAIRO 4 FROM HEALTHY AND INFESTED PLOTS EVALUATED UNDER Orobanche INFESTATION
}

(Received: 23.6.2014)

\author{
By \\ M.M. Shafik, M.M.F. Abdalla and M.M.H. Abd El-Wahab \\ Agronomy Department, Faculty of Agriciculture, Cairo University, Giza,Egypt
}

\begin{abstract}
In order to study the effect of selection in free and infested fields followed by evaluation under Orobanche infestation, 52 seed lots from variety Cairo 4 of faba beans were evaluated under Orobanche infestation. They comprised 25 seed lots (from individual plants and bulk selection) and remnant seed of the original source stored in a cold room that were handled in free soil,in addition to sister seed stocks that were grown and selected in Orobanche field. Individual selections varied significantly from bulk selections in four characters and the rigid bulk selection (1.33\%) performed better than other bulk selection intensities. The base seed stored in a cold room produced plants that were significantly inferior than some selected materials in all traits. For materials propagated under free conditions and evaluated under Orobanche, ten individual selections and one bulk were significantly taller than base materials. Similarly eleven selections and one bulk had heavier plant dry weight; four selections had more branches. Nine selections and two bulks had more pods/plant, three selections and one bulk had more seeds/plant. Six selections and one bulk had more seeds/plant, six selections and one bulk outyielded the base population, four selections and one bulk had heavier seed index. Similar results were found when plants from the original seeds were compared to those from selections that were handled and evaluated under Orobanche infestation.

Base bulk plants were significantly inferior than $25 \%$ of individual selections and $25 \%$ of selected bulks in plant height, $70 \%$ of selections and $100 \%$ of bulks for plant dry weight, $35 \%$ of selections for branches/plant, $40 \%$ of selections and $75 \%$ of bulks for pods/plant, $85 \%$ selections and $100 \%$ of bulks for seeds/plant, $65 \%$ of selections and $100 \%$ of bulks for seed yield/plant but no improvement occurred in seed index for selections. Individual and bulk selections were effective in variety Cairo 4.

Materials grown in a free field had a better performance than those grown under Orobanche when both were evaluated under Orobanche infestation. This may be due to better performance potential of materials grown in free and/or multiplication under Orobanche stress reduces potentiality of performance.
\end{abstract}

Key words: faba beans, Vicia faba, individual selection, bulk selection, selection intensity, Orobanche.

\section{INTRODUCTION}

Faba bean, Vicia faba, L. is an important human food in Egypt. Although, it is considered as self-fertilized species, cross fertilization may reach up to $67 \%$. Up to the present, hybrid varieties are not feasible in faba bean, but blended and synthetic varieties have been developed to explore heterosis in this crop (Bond, 1982 and Abdalla and Fischbeck, 1992).

Blended varieties and the pollination system will allow for the segregants of homozygous, heterozygous and heterogeneous materials within the certified varieties. What will be the effect of individual-plant selection and the bulk selection with different intensities compared to the original seeds in Cairo 4 blended variety?.

Orobanche crenata, (Forsk.) is a parasitic plant on faba bean and its seeds may live in the soil for several years without losing viability (Tewfic, 1956) until germinated by stimulants from host roots. Cairo 4 is an Orobanche tolerant variety (Abdalla and Darwish 2008). 
Considering all these facts, the present investigation was designed to study the effect of selection in free and infested fields followed by an evaluation under Orobanche infestation.

\section{MATERIALS AND METHODS}

\subsection{Location of study and plant materials:}

The materials used in the present studies belong to the variety Cairo 4. It is a synthetic Orobanche tolerant and registered as commercial variety from the Agronomy Department, Faculty of Agriculture, Cairo University.

The trials of these studies were carried out at the Agricultural Experiments and Research Station, Faculty of Agriculture, Cairo University, Giza, under two conditions (naturally Orobanche infested field and Orobanche-free field) during seasons 2008/2009, 2009/2010 and under naturally Orobanche-infested field during 2010/2011 season.

The history of chosen Orobanche field is known by its high infestation by broomrape seeds since almost 35 years ago.

In 2008 - 2009 season, seeds of variety "Cairo 4" were planted under two field conditions (Orobanche-free and infested). In addition, some of the seeds were stored in the cold room [(base bulk (Pop 6)] for evaluation in the last season.

Seeds were sown in separate plots. Each plot consisted of 55 ridges; each ridge was $3 \mathrm{~m}$ long and $60 \mathrm{~cm}$ apart. Seeds were hand planted as doubled seeds/hill, at $20 \mathrm{~cm}$ distance on one side of the ridge.

The best 160 plants (based on pod-set visual selection and the general appearance of the plants) were selected during the maturity stage.

After harvesting, the best 150 yielding plants of the 160 selected in field were divided into 4 groups based on pod and seed yield/plant [(the best 20 plants (Pop 1), the best 50 plants (Pop 2), the best 100 plants (Pop 3) and the best 150 plants (Pop 4)] with selection intensities of $1.33,3.33,6.67$ and $10 \%$, respectively. Five seeds from each plant were taken and blended to synthesize the four selected bulks of seeds. Also at harvesting, 30 plants were taken at random and their seeds were blended to constitute the bulk unselected stock (Pop 5) (Fig.1).

In addition,the remnant seeeds of the best 20 plants harvested individually were used for evaluation as individual plant selections in addition to their bulk use (Pop 1).

During 2009/2010 season the 20 individual selected plants, the 4 selected bulks (Pop 1, Pop 2, Pop 3 and Pop 4) in addition to the unselected one (Pop 5) were sown for evaluation under Orobanche-free (25 selections and populations) and Orobanche-infested field conditions (25 sister selections and populations) (Abdalla et al., 2014).

All selections and populations from both infested conditions and free ones (25 from the Orobanche-free and 25 from the Orobancheinfested) were evaluated with the stored seeds (base bulk) during 2010/2011 season under Orobanche-infested fields. The 26 stocks for each variety were

1. Twenty individual selections.

2. Four selected bulks (Pop 1, Pop 2, Pop 3 and Pop 4).

3. One unselected bulk (Pop 5).

4. One base bulk (Pop 6-stored seeds in cold room at $12^{\circ} \mathrm{c}$ ).

\subsection{Experimental design and crop managment}

In the Orobanche-infested field, the materials were sown in a randomized complete blocks design with two replications. Sowing was done on November, 25 (2010). Each plot comprised of 2 ridges of $4 \mathrm{~m}$ long and $60 \mathrm{~cm}$ wide. Seeds were sown individually on one side of the ridge at $25 \mathrm{~cm}$ between hills. All agronomic practices were keeping normal and uniform for all the treatments.

\subsection{Data collection:}

The following data were recorded from all individual plants of each experimental plot and the averages were considerd an per plant basis:

2.3. 1. Plant height $(\mathrm{cm})$.

2.3. 2. Plant dry weight (g).

2.3. 3. Number of branches/host plant.

2.3. 4. Number of pods/host plant.

2.3. 5. Number of seeds /host plant.

2.3. 6. Seed yield/host plant (g).

2.3. 7. Percentage of podded hosts /ridge (\% podded plants).

2.3.8. Number of Orobanche spikes/ridge at maturity.

2.2. 9. Seed index, 100 seeds (g).

\subsection{Statistical analysis:}

Data were statistically analyzed using analysis of variance according to Gomez and Gomez(1984) 


\begin{tabular}{|c|c|c|c|c|}
\hline & & & & \\
\hline $\begin{array}{l}\text { Bulk of } \\
\text { the best } 20\end{array}$ & $\begin{array}{l}\text { Bulk of } \\
\text { the best } 50\end{array}$ & $\begin{array}{l}\text { Bulk of } \\
\text { the best }\end{array}$ & $\begin{array}{l}\text { Bulk } \\
\text { of all the } 150\end{array}$ & $\begin{array}{l}\text { Bulk of } \\
30 \text { random plants }\end{array}$ \\
\hline plants & plants & 100 plants & plants & were used to \\
\hline$(1.33 \%)$ & $(3.33 \%)$ & $(6.67 \%)$ & $(10 \%)$ & make \\
\hline (selected bulk) & (selected bulk) & (selected bulk) & (selected bulk) & (unselected bulk) \\
\hline (Pop 1) & (Pop 2) & (Pop 3) & (Pop 4) & (Pop 5) \\
\hline
\end{tabular}

Fig.(1): Constituents of the five studied populations.

procedure for a randomized complete block design. Appropriate transformations (logarithmic, square root, arcsin) were performed when necessary. Treatment means were compared using Duncan's Multiple Range test (DMRT) (Steel et al., 1997). Finally, all statistical analysis were carried out using "MSTAT-C" (Freed et al., 1989).

\section{RESULTS AND DISCUSSION}

The 52 seed lots of variety Cairo 4 (25 from free plots and 25 from infested ones, in addition to two original seeds lots stored in the cold room) were evaluated during 2010/2011 season under Orobanche infestation showed the following results.

\subsection{Selections from the free field evaluated under Orobanche infestation.}

\subsubsection{Analysis of variance and significance of} variances due to the 26 seed lots

Analysis of variance and the significance of mean squares due to different sources of variation for the studied traits are presented in Table (1). Results of statistical analysis revealed that the variances due to genetic sources were highly significant (or significant), for all traits except the number of Orobanche/ridge.

Three allowed orthogonal comparisons; the first one selections (the best 20 selected individual plants) vs. bulks (Pop 1, Pop 2, Pop 3, Pop 4 and Pop 5), the second Pop1 vs. Pop 2 and the third (Pop 1, Pop 2, Pop 3, and Pop $4 v s$. Pop5) were performed and presented in Table (1).

Data reported in Table (1) demonstrated that in the first comparison (selections $v s$. bulks) there was highly significant variation for plant height, plant dry weight, number of branches/plant and seed yield/plant, while the second one (Pop $1 v s$. Pop 2) it was significant for plant dry weight, number of seeds/plant, seed yield/plant and seed index. On the other hand, comparing selected and unselected bulks indicated the absence of significant differences between these two populations for all the studied traits, except for number of pods/plant.

According to variance analysis, the comparison of individual selection vs. bulks showed higher variances than other comparisons for plant height, plant dry weight, branches/plant and seed yield/plant. This means that, each group of selections possessed its own distinct characteristic, which is reflected in high variability.

Also, this reflection appeared in the comparison between Pop 1 vs. Pop 2 for number of seeds/plant, seed index and podded plants $\%$. On the other hand, the highest significance was found for number of pods/plant in comparing selected populations to unselected bulk. These offer an important opportunity for selecting populations and selections that exhibit variable performance from each selection intensity or individual selection.

\subsubsection{Mean performance of the 26 selections and populations}

The mean performance of the studied traits for the selected and unselected genotypes is illustrated in Table (2). All traits recorded significant differences under the field of infestation except the number of Orobanche/ridge (Table 1). The mean performance varied significantly within the individuals to bulks. The averages differed from one individual selection to another, selected bulk to bulk and from all genotypes to the unselected (Pop 5) and the original base bulk population (original stored seeds, Pop 6). 
Table (1): Significance of mean squares of variety Cairo 4 selections and populations (26 populations from free conditions) under Orobanche-infested condition during 2010/2011 season

\begin{tabular}{|c|c|c|c|c|c|c|c|c|c|c|}
\hline \multirow[b]{2}{*}{ S.O.V. } & \multirow[b]{2}{*}{ df } & \multicolumn{9}{|c|}{ Mean squares } \\
\hline & & $\begin{array}{l}\text { Plant } \\
\text { height }\end{array}$ & $\begin{array}{c}\text { Plant } \\
\text { dry } \\
\text { weight }\end{array}$ & \begin{tabular}{|c|} 
No. \\
branches \\
/plant
\end{tabular} & $\begin{array}{c}\text { No. } \\
\text { pods } \\
\text { /plant }\end{array}$ & $\begin{array}{l}\text { No. } \\
\text { seeds } \\
\text { /plant }\end{array}$ & $\begin{array}{c}\text { Seed } \\
\text { yield/plant }\end{array}$ & $\begin{array}{l}\text { Seed } \\
\text { index }\end{array}$ & $\begin{array}{c}\text { Podded } \\
\text { plants } \\
(\%)\end{array}$ & $\begin{array}{c}\text { No. } \\
\text { Orobanc } \\
\text { hel } \\
\text { ridge }\end{array}$ \\
\hline Seed materials & 25 & $88.90 * *$ & $287.49 * *$ & $0.69 * *$ & $44.25 * *$ & $103.80 * *$ & $40.24 * *$ & $138.92 * *$ & $201.94 *$ & $0.02 \mathrm{~ns}$ \\
\hline $\begin{array}{c}\text { Individual } \\
\text { Selections vs. } \\
\text { bulks }\end{array}$ & 1 & $433.34 * *$ & $\begin{array}{c}1483.33 * \\
*\end{array}$ & $0.42 *$ & $10.59 \mathrm{~ns}$ & $26.68 \mathrm{~ns}$ & $49.00 * *$ & $51.63 \mathrm{~ns}$ & $61.21 \mathrm{~ns}$ & $0.01 \mathrm{~ns}$ \\
\hline Pop1 vs. Pop2 & 1 & $44.09 \mathrm{~ns}$ & $784.00 * *$ & $0.22 \mathrm{~ns}$ & $7.13 \mathrm{~ns}$ & $505.35 * *$ & $33.64 *$ & $275.89 * *$ & $240.25 \mathrm{~ns}$ & $0.01 \mathrm{~ns}$ \\
\hline $\begin{array}{c}\text { Pop1, 2, } 3 \& 4 \\
\text { vs. Pop5 } \\
\end{array}$ & 1 & $1.75 \mathrm{~ns}$ & $46.05 \mathrm{~ns}$ & $0.03 \mathrm{~ns}$ & $21.17 *$ & $2.08 \mathrm{~ns}$ & $1.48 \mathrm{~ns}$ & $0.07 \mathrm{~ns}$ & $25.60 \mathrm{~ns}$ & $0.00 \mathrm{~ns}$ \\
\hline Residual & 22 & $79.24 * *$ & $221.54 * *$ & $0.75 \mathrm{~ns}$ & $48.52 * *$ & $93.68 * *$ & $41.90 * *$ & $142.97 * *$ & $214.61 * *$ & $0.02 \mathrm{~ns}$ \\
\hline Error & 25 & 12.11 & 22.05 & 0.08 & 4.52 & 11.03 & 6.72 & 17.34 & 99.64 & 0.02 \\
\hline
\end{tabular}

$\mathrm{ns}, * * *$ * not significant, significant at 0.05 and 0.01 levels of probability, respectively.

The individual selection from free conditions (ISF3), produced the highest number of branches, pods and seed yield/plant (5.0 branches, 36.7 pods and $43.3 \mathrm{~g}$, respectively). In respect to bulks, Pop 1 exhibited higher values of each of plant dry weight (112.1 g),the number of branches (3.6), the number of pods/plant (26.1), number of seeds/plant (67.3) and seed yield/plant (39.6 g), while the blend of Pop 2 produced the shortest plant height and plant dry weight $(71.9 \mathrm{~cm}$ and $84.1 \mathrm{~g})$. Also, results demonstrated that, different performances were found for the other traits and groups. The ISF17 had the tallest plants $(94.6 \mathrm{~cm})$ and ISF6 had the heaviest dry weight $(132.3 \mathrm{~g})$. The highest number of seeds/plant was recorded in ISF5 (70.6) while the heaviest seed index was recorded in ISF12 (94.7 g).

Five individual selected plants (ISF7, ISF8, ISF14, ISF15 and ISF18) exhibited the full percentage $(100 \%)$ for podded plants. The highest level of infestation/ridge (55.0 spikes) was accompanied by seed yield per plant (33.5 g) for the selection ISF9. In spite of the lowest level of infestation with broomrape/ridge (24.0 spikes) observed for Pop 4, the population possessed the least seed yield/plant $(28.0 \mathrm{~g})$. ISF8 possessed the lowest number of pods/plant (17.4), ISF14 had the lowest seed index $(56.3 \mathrm{~g})$ and ISF13 possessed the lowest podded $\%$ (75.0\%) and expressed one of the low seed yield per plant $(30.4 \mathrm{~g})$.
The comparison between different bulk selection intensities revealed high performance for the blend of Pop 1 which had the highest plant dry weight, seeds per plant (ranked second) and seed yield/plant (ranked 6) (112.1 g, 67.3 seeds and $39.6 \mathrm{~g}$, respectively). In contrast, the high level of infestation with the parasitic plant (44.5 spikes) in Pop 1, it had the insignificant lowest podded plants\% $(83.5 \%)$ in all bulks. On the other hand, the blend of Pop 3 had taller plants $(87.1 \mathrm{~cm})$ and the highest number of pods/plant (27.1 pods), whereas the heaviest seed index and the highest podded plants\% (75.5 $\mathrm{g}$ and $95.8 \%$, respectively) were recorded for the blend of Pop 2. In spite of the highest number of branches/plant (3.7 branches) and the lowest number of Orobanche/ridge (24.0 spikes) which recorded for Pop 4, it produced the lowest seed yield (28.0 g) and seed index (58.3 g) in bulks. Pop 2 had the shortest plants (71.9 $\mathrm{cm}$ ), while Pop 3 expressed the lowest number of branches per plant (2.9 branches).

One of the objectives of this study was to detect the effect of selection, individual and bulk. The comparison between the base seeds bulk (stored in the cold room) and the other selected materials (handled during 2008/2009 and 2009/2010) indicated that the base bulk was significantly inferior than some selected materials in all traits. Ten individual selections and Pop 3 were significantly taller than base bulk. Eleven individual selections and Pop 1 had significantly heavier plant dry weight than base 
Table (2): Mean traits of selections and populations (resulted under free infested) from variety Cairo 4 grown under Orobanche-infested condition during 2010/2011 season.

\begin{tabular}{|c|c|c|c|c|c|c|c|c|c|}
\hline Code & $\begin{array}{c}\text { Plant } \\
\text { height } \\
(\mathrm{cm})\end{array}$ & $\begin{array}{l}\text { Plant dry } \\
\text { weight } \\
\text { (g) }\end{array}$ & $\begin{array}{c}\text { No. } \\
\text { branches/ } \\
\text { plant }\end{array}$ & $\begin{array}{l}\text { No. } \\
\text { pods/ } \\
\text { plant }\end{array}$ & $\begin{array}{l}\text { No. } \\
\text { seeds/ } \\
\text { plant }\end{array}$ & $\begin{array}{c}\text { Seed yield/ } \\
\text { plant (g) }\end{array}$ & $\begin{array}{c}\text { Seed } \\
\text { index }(g)\end{array}$ & $\begin{array}{c}\text { Podded } \\
\text { plants } \\
(\%)\end{array}$ & $\begin{array}{c}\text { No. } \\
\text { Orobanche/ } \\
\text { ridge }\end{array}$ \\
\hline ISF1 & $89.3 \mathrm{a}-\mathrm{e}$ & $107.6 \mathrm{e}-\mathrm{g}$ & $2.9 \mathrm{fg}$ & $22.9 \mathrm{f}-\mathrm{i}$ & $62.3 \mathrm{bc}$ & $40.8 \mathrm{ab}$ & $65.6 \mathrm{c}-\mathrm{f}$ & $76.4 \mathrm{bc}$ & $38.0 \mathrm{~h}$ \\
\hline ISF2 & $82.5 \mathrm{e}-\mathrm{g}$ & $118.2 \mathrm{a}-\mathrm{d}$ & $4.3 \mathrm{bc}$ & $33.7 \mathrm{ab}$ & $47.1 \mathrm{~h}-\mathrm{j}$ & $34.2 \mathrm{~d}-\mathrm{g}$ & $72.7 b c$ & $86.8 \mathrm{a}-\mathrm{c}$ & $48.0 \mathrm{c}$ \\
\hline ISF3 & $91.2 \mathrm{a}-\mathrm{d}$ & $125.3 \mathrm{ab}$ & $5.0 \mathrm{a}$ & $36.7 \mathrm{a}$ & $66.8 \mathrm{ab}$ & $43.3 \mathrm{a}$ & $64.8 \mathrm{c}-\mathrm{f}$ & $93.5 \mathrm{a}-\mathrm{c}$ & $36.5 \mathrm{j}$ \\
\hline ISF4 & $79.7 \mathrm{~g}-\mathrm{i}$ & $105.2 \mathrm{fg}$ & $3.8 \mathrm{~cd}$ & $30.4 b c$ & $56.3 \mathrm{c}-\mathrm{f}$ & $39.1 \mathrm{a}-\mathrm{d}$ & $69.5 b-d$ & $85.4 \mathrm{a}-\mathrm{c}$ & $31.0 \mathrm{n}$ \\
\hline ISF5 & $82.9 \mathrm{e}-\mathrm{g}$ & $120.1 b c$ & $3.5 \mathrm{de}$ & $28.9 \mathrm{~cd}$ & $70.6 \mathrm{a}$ & $42.2 \mathrm{a}$ & $59.8 \mathrm{e}-\mathrm{g}$ & $83.3 a-c$ & $47.0 \mathrm{~d}$ \\
\hline ISF6 & $91.7 \mathrm{a}-\mathrm{c}$ & $132.3 \mathrm{a}$ & $3.9 \mathrm{~cd}$ & $28.1 \mathrm{c}-\mathrm{e}$ & 55.4d-f & $40.3 \mathrm{ab}$ & $73.3 b c$ & $82.2 \mathrm{a}-\mathrm{c}$ & $30.5 \mathrm{o}$ \\
\hline ISF7 & $83.6 \mathrm{e}-\mathrm{g}$ & $113.5 \mathrm{c}-\mathrm{f}$ & $3.5 \mathrm{de}$ & $21.5 \mathrm{~h}-\mathrm{k}$ & 59.0c-e & $36.4 b-f$ & $61.5 \mathrm{~d}-\mathrm{g}$ & $100.0 \mathrm{a}$ & $24.5 \mathrm{~s}$ \\
\hline ISF8 & $\mid 84.8 \mathrm{c}-\mathrm{g}$ & $86.2 \mathrm{ij}$ & $2.9 \mathrm{fg}$ & $17.4 \mathrm{k}$ & $44.5 \mathrm{ij}$ & $30.9 \mathrm{gh}$ & $69.7 \mathrm{~b}-\mathrm{d}$ & $100.0 \mathrm{a}$ & $24.5 \mathrm{~s}$ \\
\hline ISF9 & $72.1 \mathrm{j}$ & $85.6 \mathrm{ij}$ & $3.7 \mathrm{~d}$ & $24.1 \mathrm{e}-\mathrm{h}$ & $44.4 \mathrm{j}$ & $33.5 \mathrm{e}-\mathrm{g}$ & $75.6 \mathrm{~b}$ & $84.9 \mathrm{a}-\mathrm{c}$ & $55.0 \mathrm{a}$ \\
\hline ISF10 & $79.0 \mathrm{~g}-\mathrm{j}$ & $104.8 \mathrm{fg}$ & $3.1 \mathrm{e}-\mathrm{g}$ & $24.3 \mathrm{e}-\mathrm{h}$ & $56.3 \mathrm{c}-\mathrm{f}$ & $33.1 \mathrm{f}-\mathrm{h}$ & $58.8 \mathrm{e}-\mathrm{g}$ & $76.4 \mathrm{bc}$ & 32.51 \\
\hline ISF11 & $74.1 \mathrm{~h}-\mathrm{j}$ & 106.1e-g & $2.8 \mathrm{~g}$ & $33.5 \mathrm{ab}$ & 61.6b-d & 38.6a-e & $62.7 \mathrm{~d}-\mathrm{g}$ & $90.0 \mathrm{a}-\mathrm{c}$ & $32.0 \mathrm{~m}$ \\
\hline ISF12 & $84.2 \mathrm{~d}-\mathrm{g}$ & $105.1 \mathrm{fg}$ & $4.6 a b$ & $19.1 \mathrm{i}-\mathrm{k}$ & $45.3 \mathrm{ij}$ & $42.9 \mathrm{a}$ & $94.7 \mathrm{a}$ & $86.4 \mathrm{a}-\mathrm{c}$ & $29.5 p$ \\
\hline ISF13 & $84.3 \mathrm{~d}-\mathrm{g}$ & $112.7 \mathrm{c}-\mathrm{f}$ & $3.1 \mathrm{e}-\mathrm{g}$ & $21.8 \mathrm{~g}-\mathrm{j}$ & $53.2 \mathrm{e}-\mathrm{h}$ & $30.4 \mathrm{gh}$ & $57.2 \mathrm{fg}$ & $75.0 \mathrm{c}$ & $39.0 \mathrm{~g}$ \\
\hline ISF14 & $85.4 \mathrm{c}-\mathrm{g}$ & 109.0d-g & 3.4d-f & $21.5 \mathrm{~h}-\mathrm{k}$ & $58.2 \mathrm{c}-\mathrm{e}$ & $32.8 \mathrm{f}-\mathrm{h}$ & $56.3 \mathrm{~g}$ & $100.0 \mathrm{a}$ & $26.5 \mathrm{r}$ \\
\hline ISF15 & $83.1 \mathrm{e}-\mathrm{g}$ & $111.5 \mathrm{c}-\mathrm{f}$ & $3.9 \mathrm{~cd}$ & 25.6d-h & $51.0 \mathrm{f}-\mathrm{j}$ & $30.7 \mathrm{gh}$ & $60.2 \mathrm{e}-\mathrm{g}$ & $100.0 \mathrm{a}$ & $26.5 \mathrm{r}$ \\
\hline ISF16 & $91.2 \mathrm{a}-\mathrm{d}$ & $115.4 \mathrm{c}-\mathrm{e}$ & $3.7 \mathrm{~d}$ & $23.5 \mathrm{f}-\mathrm{h}$ & $56.2 \mathrm{c}-\mathrm{f}$ & $34.1 \mathrm{~d}-\mathrm{g}$ & $60.7 \mathrm{e}-\mathrm{g}$ & $81.8 \mathrm{a}-\mathrm{c}$ & $38.0 \mathrm{~h}$ \\
\hline ISF17 & $94.6 \mathrm{a}$ & $104.8 \mathrm{fg}$ & $2.8 \mathrm{~g}$ & $22.2 \mathrm{~g}-\mathrm{j}$ & $50.5 f-j$ & $29.3 \mathrm{gh}$ & $57.9 \mathrm{e}-\mathrm{g}$ & $78.0 \mathrm{bc}$ & $52.5 \mathrm{~b}$ \\
\hline ISF18 & $81.3 \mathrm{fg}$ & $118.0 \mathrm{~b}-\mathrm{d}$ & $4.5 \mathrm{ab}$ & $25.1 \mathrm{~d}-\mathrm{h}$ & $51.1 \mathrm{f}-\mathrm{j}$ & $30.0 \mathrm{gh}$ & $58.6 \mathrm{e}-\mathrm{g}$ & $100.0 \mathrm{a}$ & $31.0 \mathrm{n}$ \\
\hline ISF19 & $94.0 \mathrm{ab}$ & $111.8 \mathrm{c}-\mathrm{f}$ & 3.6de & $27.1 \mathrm{c}-\mathrm{f}$ & $59.4 c-e$ & $38.7 \mathrm{a}-\mathrm{e}$ & $65.2 \mathrm{c}-\mathrm{f}$ & $96.2 \mathrm{ab}$ & $29.0 \mathrm{q}$ \\
\hline ISF20 & $91.9 \mathrm{a}-\mathrm{c}$ & $105.4 \mathrm{fg}$ & $2.7 \mathrm{~g}$ & $18.4 \mathrm{jk}$ & $51.0 f-j$ & $33.7 \mathrm{e}-\mathrm{g}$ & $66.1 \mathrm{c}-\mathrm{e}$ & $89.3 a-c$ & $24.0 \mathrm{t}$ \\
\hline Mean & 85.1 & 109.9 & 3.6 & 25.3 & 55.0 & 35.7 & 65.6 & 88.3 & 34.8 \\
\hline Pop1 & $78.5 \mathbf{g}-\mathbf{j}$ & $112.1 \mathbf{c - f}$ & 3.6de & $26.1 \mathrm{c}-\mathrm{g}$ & $67.3 \mathrm{ab}$ & $39.6 a-c$ & $58.9 \mathrm{e}-\mathrm{g}$ & $83.5 a-c$ & $44.5 \mathrm{e}$ \\
\hline Pop2 & $71.9 \mathrm{j}$ & $84.1 \mathrm{j}$ & $3.1 \mathrm{e}-\mathrm{g}$ & $23.4 \mathrm{f}-\mathrm{i}$ & $44.8 \mathrm{ij}$ & $33.8 \mathrm{~d}-\mathrm{g}$ & $75.5 b$ & $95.8 \mathrm{ab}$ & $34.0 \mathrm{k}$ \\
\hline Pop3 & 87.1 b-f & 94.5 hi & $2.9 \mathrm{fg}$ & $27.1 \mathrm{c}-\mathrm{f}$ & $53.8 \mathrm{e}-\mathrm{h}$ & 33.0f-h & $61.3 \mathrm{~d}-\mathrm{g}$ & $87.8 \mathrm{a}-\mathrm{c}$ & $44.0 \mathrm{f}$ \\
\hline Pop4 & 72.9ij & $88.7 \mathrm{ij}$ & $3.7 \mathrm{~d}$ & $23.8 \mathrm{e}-\mathrm{h}$ & $48.0 \mathrm{~g}-\mathrm{j}$ & $28.0 \mathrm{~h}$ & $58.3 \mathrm{e}-\mathrm{g}$ & $86.4 a-c$ & $24.0 \mathrm{t}$ \\
\hline Mean & 77.6 & 94.9 & 3.3 & 25.1 & 53.5 & 33.6 & 63.5 & 88.4 & 36.6 \\
\hline Pop5 & $80.2 \mathrm{f}-\mathrm{h}$ & 103.9f-h & $3.4 \mathrm{~d}-\mathrm{f}$ & $23.5 \mathrm{f}-\mathrm{h}$ & $51.3 \mathrm{f}-\mathrm{i}$ & $31.6 \mathrm{f}-\mathrm{h}$ & $61.7 \mathrm{~d}-\mathrm{g}$ & $85.0 \mathrm{a}-\mathrm{c}$ & $38.0 \mathrm{~h}$ \\
\hline $\begin{array}{c}\text { Base Bulk } \\
\text { Pop6 }\end{array}$ & $78.6 \mathrm{~g}-\mathrm{j}$ & 100.2gh & 3.5de & 21.5h-k & 54.6e-g & $34.6 \mathrm{c}-\mathrm{g}$ & 63.3d-g & 88.5a-c & 37.0i \\
\hline G. mean & 83.5 & 107.0 & 3.5 & 25.0 & 54.6 & 35.2 & 65.0 & 88.2 & 35.3 \\
\hline
\end{tabular}

ISF1, ISF2, ISF3 = Individual selection number one, two and three, respectively under free field from the previous $2009 / 2010$ season. G. mean $=$ Grand mean.

Means followed by the same letter(s) in the same column are not significantly different. 
bulk. Only 4 selections had significantly more branches than base bulk. Nine selections and Pop 1 and Pop 3 had significantly higher pod set than base bulk. Three selections and Pop1 had significantly more seeds per plant than base bulk. Six selections and Pop 1 significantly outyielded the base bulk. Four selections and Pop 2 had heavier seed index compared to base bulk. The characteristics related to Orobanche parasitism showed that percentage of podded plants was $88.5 \%$ in the base bulk against $88.2 \%$ for the grand mean and ranged between 75 and $100 \%$ whereas, number of Orobanche spikes of the base bulk was 37.0 compared to a grand mean of 35.3 spikes and ranged between 24.0 and 55 spikes per ridge. It is therefore clear that selection in the variety Cairo 4 was effective.

Concerning mass selection, one bulk (25\%) was significantly superior than base bulk. However, for individual selection from 3 (15\%) to $11(55 \%)$ selections significantly performed better than the original seeds (base bulk) (see also Abdalla, 1976; Abdalla and Darwish, 1994; Ashrie et al., 2010 and Abdalla et al., 2012).

\subsection{Selections from infested field grown under Orobanche infestation}

\subsubsection{Analysis of variance and significance of variances due to 26 seed lots}

In the present study, the results of variance analysis are shown in Table (3), the significance of mean squares due to different genetic resources for the studied traits during 2010/2011 season is presented in Table (3). The variance analysis results showed that, highly significant differences were found among the genotypes for all traits under the study, except for the number of Orobanche/ridge under the infested field.

Three allowed orthogonal comparisons; individual selections (the best 20 selected individual plants) vs. bulks (Pop 1, Pop 2, Pop 3, Pop 4 and Pop 5), Pop 1 vs. Pop 2, and (Pop 1, Pop 2, Pop 3, and Pop 4 vs. Pop 5) were performed and presented in Table (3). Statistical analysis of the data also revealed that, significant differences were recorded for number of branches/plant, seeds/plant, seed index and Orobanche/ridge by comparison of individual selections vs. bulks while, the second one (Pop 1 $v s$. Pop 2) showed highly significant differences for plant dry weight, number of seeds/plant and seed yield/plant. Comparison of selected and unselected bulks revealed highly significant differences among genotypes for plant dry weight, pods/plant, seeds/plant, seed yield/plant and seed index.
Based on the results of the analysis of variances, data revealed that high variance was recorded for seed index, podded plants $\%$ and number of Orobanche/ridge when comparing individual selection $v s$. bulks and for seed yield/plant, when comparing Pop $1 v s$. Pop 2. On the other hand, comparison of the selected $v s$. the unselected bulk showed high variance for plant height, plant dry weight, pods/plant and seeds per plant.

\subsubsection{Mean performance of the 26 selections and populations}

The mean performance of individual selected genotypes and populations is presented in Table (4). Mean performance differed from individual selection to another, from selected individuals to selected bulks, from bulk to bulk and from all genotypes to the original base seed bulk.

Concerning the individual selections grown in 2010/2011 season in infested conditions, ISF3 showed the maximum seed yield/plant, seed index and podded plants $\%$ (33.4 g, $79.5 \mathrm{~g}$ and $100 \%$, respectively), while the ISF5 produced the highest pods/plant (13.7 pods) and ISF4 had the greatest number of seeds/plant (46.1 seeds). The plants of ISF16 were the tallest $(78.8 \mathrm{~cm})$ while the highest plant dry weight $(58.4 \mathrm{~g})$ was recorded for ISF2. Pop 1 ranked first for the level of infestation with parasitic plants (42.0 spikes) while ISF17 and Pop 2 ranked second for the same trait (41.5 and 41.5 spikes, respectively). The plants of ISF15 were the shortest $(62.7 \mathrm{~cm})$, while the ISF20 had the lowest plant dry weight $(36.3 \mathrm{~g})$. Lower number of pods and number of seeds/plant (7.5 pods and 18.6 seeds) was recorded for ISF18. The lowest seed yield/plant (13.2 g) was recorded for unselected bulk (Pop5). ISF4 had the lowest seed index $(59.8 \mathrm{~g})$ and ISF17 had the lowest podded plants $(74.5 \%)$ while the ISF11 exhibited the lowest level of infestation/ridge (19.5 spikes).

For bulks, the comparison between different selection intensities revealed high performance for the blend of Pop 1 which had the highest plant height, plant dry weight, number of seeds, seed yield/plant and seed index $(76.0 \mathrm{~cm}, 55.3 \mathrm{~g}$, 39.4 seeds, $30.9 \mathrm{~g}$ and $78.3 \mathrm{~g}$, respectively) and had also the highest level of infestation (42.0 spikes) across all bulks and ranked third for plant height, plant dry weight, and seed yield/plant and second for seed index over all genotypes. But, the lowest branches/plant was recorded for Pop1 (2.3). The bulk selection Pop4 possessed the highest branches/plant and 
Table (3): Significance of mean squares of variety Cairo 4 selections and populations (26 infested) under Orobanche-infested condition during 2010/2011 season

\begin{tabular}{|c|c|c|c|c|c|c|c|c|c|c|}
\hline \multirow[b]{2}{*}{ S.O.V. } & \multirow[b]{2}{*}{ df } & \multicolumn{9}{|c|}{ Mean squares } \\
\hline & & $\begin{array}{l}\text { Plant } \\
\text { height }\end{array}$ & $\begin{array}{c}\text { Plant } \\
\text { dry } \\
\text { weight }\end{array}$ & \begin{tabular}{|} 
No. \\
branches \\
/plant
\end{tabular} & $\begin{array}{c}\text { No. } \\
\text { pods } \\
\text { /plant }\end{array}$ & $\begin{array}{l}\text { No. } \\
\text { seeds } \\
\text { /plant }\end{array}$ & $\begin{array}{c}\text { Seed } \\
\text { yield/plant }\end{array}$ & $\begin{array}{l}\text { Seed } \\
\text { index }\end{array}$ & $\begin{array}{c}\text { Podded } \\
\text { plants } \\
(\%)\end{array}$ & \begin{tabular}{|} 
No. \\
Orobanche/ \\
ridge
\end{tabular} \\
\hline $\begin{array}{c}\text { Seed } \\
\text { materials }\end{array}$ & 25 & $\begin{array}{c}28.40 \\
* *\end{array}$ & $\begin{array}{c}65.53 \\
* *\end{array}$ & $\begin{array}{c}0.21 \\
* *\end{array}$ & $\begin{array}{l}5.24 \\
* *\end{array}$ & $\begin{array}{c}111.51 \\
* *\end{array}$ & $\begin{array}{c}57.65 \\
* *\end{array}$ & $\begin{array}{c}55.24 \\
* *\end{array}$ & $\begin{array}{c}199.12 \\
*\end{array}$ & $\begin{array}{c}0.02 \\
\mathrm{~ns}\end{array}$ \\
\hline $\begin{array}{c}\text { Individual } \\
\text { Selections } \\
\text { vs. bulks } \\
\end{array}$ & 1 & $\begin{array}{c}6.01 \\
\mathrm{~ns}\end{array}$ & $\begin{array}{c}9.21 \\
\mathrm{~ns}\end{array}$ & $\begin{array}{c}0.44 \\
* *\end{array}$ & $\begin{array}{c}0.02 \\
\mathrm{~ns}\end{array}$ & $\begin{array}{c}38.06 \\
* *\end{array}$ & $\begin{array}{c}3.43 \\
\mathrm{~ns}\end{array}$ & $66.26^{*}$ & $182.11 \mathrm{~ns}$ & $\begin{array}{c}0.09 \\
* *\end{array}$ \\
\hline $\begin{array}{l}\text { Pop1 vs. } \\
\text { Pop2 }\end{array}$ & 1 & $\begin{array}{c}5.95 \\
\text { ns }\end{array}$ & $\begin{array}{c}79.03 \\
*\end{array}$ & $\begin{array}{c}0.23 \\
\mathrm{~ns}\end{array}$ & $\begin{array}{c}0.81 \\
\mathrm{~ns}\end{array}$ & $\begin{array}{c}137.36 \\
* *\end{array}$ & $\begin{array}{c}109.41 \\
* *\end{array}$ & $22.75 n s$ & $36.00 \mathrm{~ns}$ & $\begin{array}{c}0.00 \\
\mathrm{~ns}\end{array}$ \\
\hline $\begin{array}{c}\text { Pop1, 2, } 3 \\
\text { \& } 4 \text { vs. } \\
\text { Pop5 } \\
\end{array}$ & 1 & $\begin{array}{c}8.08 \\
\mathrm{~ns}\end{array}$ & $\begin{array}{c}133.74 \\
* *\end{array}$ & $\begin{array}{c}0.01 \\
\mathrm{~ns}\end{array}$ & $\begin{array}{c}13.32 \\
*\end{array}$ & $\begin{array}{c}207.48 \\
* *\end{array}$ & $\begin{array}{c}76.73 \\
* *\end{array}$ & $\begin{array}{c}59.49 \\
*\end{array}$ & $\begin{array}{c}15.63 \\
\mathrm{~ns}\end{array}$ & $\begin{array}{c}0.00 \\
\mathrm{~ns}\end{array}$ \\
\hline Residual & 22 & $\begin{array}{c}31.36 \\
* *\end{array}$ & $\begin{array}{c}64.38 \\
* *\end{array}$ & $\begin{array}{c}0.21 \\
\mathrm{~ns}\end{array}$ & $\begin{array}{c}5.31 \\
* *\end{array}$ & $\begin{array}{c}109.31 \\
* *\end{array}$ & $\begin{array}{c}56.89 \\
* *\end{array}$ & $\begin{array}{c}56.02 \\
* *\end{array}$ & $\begin{array}{c}215.65 \\
* *\end{array}$ & $\begin{array}{c}0.02 \\
\mathrm{~ns}\end{array}$ \\
\hline Error & 25 & 9.00 & 10.91 & 0.06 & 2.11 & 4.72 & 1.79 & 9.52 & 89.65 & 0.01 \\
\hline
\end{tabular}

ns, *,** = not significant, significant at 0.05 and 0.01 levels of probability, respectively.

pods/plant (3.1 branches and 11.9 pods) but had the shortest plant height and seed index $(66.9 \mathrm{~cm}$ and $66.6 \mathrm{~g}$, respectively). Pop 5 showed the lowest seeds and seed yield/plant (18.7 seeds and $13.2 \mathrm{~g}$, respectively). Pop 2 had the lowest percentage of pod bearing plants $(78.5 \%)$ and the lowest level of infestation (25.0 spikes) but Pop 3 had the highest pod bearing plants (100\%) (see Abdalla, 1976 and Abdalla et al., 2012 for similar effects of successful selection in faba bean).

The effects of selection may be detected from the comparison between individual (20) and bulk selections (4 populations) and each of Pop 5 and the base seed stock (base bulk-Pop 6) that was stored in the cold room.

The data in Table (4) showed that the base bulk was significantly inferior in plant height than $25 \%$ of individual selections and $25 \%$ of selected bulks. For plant dry weight, base bulk had significantly less weight than $70 \%$ of selections and $100 \%$ of selected bulks. The base bulk had significantly less number of branches than $35 \%$ of individual selections and did not differ significantly from selected bulks. Number of pods per plant indicated that base bulk was significantly of less pod set than $40 \%$ of selections and $75 \%$ of selected bulks. As for number of seeds per plant, base bulk was significantly inferior than $85 \%$ of individual selections and $100 \%$ of selected bulks. Seed yield per plant showed the base bulk to be statistically inferior than $65 \%$ of selections and $100 \%$ of selected bulks. As for seed index, it was the only trait in which none of the selected individuals and none of selected bulks showed superiority over the base bulk. Percentage of podded plants of the base bulk $(89.1 \%)$ was relatively less than average of all the materials (91.9). On the other hand, number of Orobanche spikes per ridge was 37.5 for base bulk. The mean of all materials was lower (30.3 spikes) and the trait ranged from 19.5 spikes (ISI11) to 42.0 spikes per ridge (Pop1).

\section{Conclusions}

Based on the results obtained, it could be conculuded that:

It is clear that, selection in Cairo 4 variety was effective wether on individual plant bases or on bulk bases.

The relative performance (comparisons exhibited of general means) of materials selected and evaluated under Orobanche parasitism was $87 \%$ for plant height, $45 \%$ for plant dry weight, $83 \%$ for branches per plant, $42 \%$ for pods per plant, $56 \%$ of seeds per plant, $62 \%$ of seed yield per plant, $108 \%$ of seed index, $104 \%$ of percentages of podded plants and $86 \%$ of Orobanche spikes per ridge, of plants grown under free condition and evaluated following season under Orobanche parasitizm. The data indicate that for variety Cairo 4, it would not make any difference if the materials evaluated under Orobanche were initially grown under 
Table (4): Mean performance of selections and populations from variety Cairo 4 (26 infested) grown under Orobanche-infested conditions during 2010/2011 season

\begin{tabular}{|c|c|c|c|c|c|c|c|c|c|}
\hline Code & $\begin{array}{c}\text { Plant } \\
\text { height } \\
(\mathbf{c m})\end{array}$ & $\begin{array}{c}\text { Plant } \\
\text { dry } \\
\text { weight } \\
\text { (g) } \\
\end{array}$ & $\begin{array}{c}\text { No. } \\
\text { branches } \\
\text { /plant }\end{array}$ & $\begin{array}{l}\text { No. } \\
\text { pods/ } \\
\text { plant }\end{array}$ & $\begin{array}{l}\text { No. } \\
\text { seeds/ } \\
\text { plant }\end{array}$ & $\begin{array}{c}\text { Seed } \\
\text { yield/ } \\
\text { plant (g) }\end{array}$ & $\begin{array}{l}\text { Seed } \\
\text { index } \\
(\mathrm{g})\end{array}$ & $\begin{array}{c}\text { Podded } \\
\text { plants } \\
(\%)\end{array}$ & \begin{tabular}{|} 
No. \\
Orobanche/ \\
ridge
\end{tabular} \\
\hline ISI1 & 74.6a-e & $50.7 \mathrm{~b}-\mathrm{g}$ & $3.2 \mathrm{a}-\mathrm{c}$ & $11.5 \mathrm{a}-\mathrm{d}$ & $32.3 \mathrm{~d}-\mathrm{f}$ & $21.9 \mathrm{~d}-\mathrm{g}$ & $67.7 e-j$ & $82.4 a-c$ & $40.5 \mathrm{~d}$ \\
\hline ISI2 & 74.7 a-e & $58.4 \mathrm{a}$ & $2.6 \mathrm{~d}-\mathrm{g}$ & $11.1 \mathrm{a}-\mathrm{e}$ & $31.8 \mathrm{e}-\mathrm{g}$ & $23.2 \mathrm{c}-\mathrm{e}$ & $73.2 \mathrm{a}-\mathrm{f}$ & $90.0 \mathrm{a}-\mathrm{c}$ & $38.0 \mathrm{e}$ \\
\hline ISI3 & $78.2 \mathrm{a}$ & $5 b 1.0 b-f$ & 2.9a-f & $11.9 \mathrm{a}-\mathrm{c}$ & $42.1 \mathrm{ab}$ & $33.4 \mathrm{a}$ & $79.5 \mathrm{a}$ & $100.0 \mathrm{a}$ & $21.0 \mathrm{r}$ \\
\hline ISI4 & $69.1 \mathrm{e}-\mathrm{g}$ & $51.2 \mathrm{~b}-\mathrm{e}$ & $3.2 \mathrm{a}-\mathrm{c}$ & $12.6 \mathrm{ab}$ & $46.1 \mathrm{a}$ & $27.6 b$ & $59.8 \mathrm{k}$ & $96.4 \mathrm{ab}$ & $24.0 \mathrm{o}$ \\
\hline ISI5 & 74.9 a-e & $49.3 \mathrm{~b}-\mathrm{g}$ & $3.0 \mathrm{a}-\mathrm{e}$ & $13.7 \mathrm{a}$ & $44.6 \mathrm{a}$ & $30.9 a$ & $69.2 \mathrm{~d}-\mathrm{h}$ & $87.8 \mathrm{a}-\mathrm{c}$ & $41.0 \mathrm{c}$ \\
\hline ISI6 & $77.2 \mathrm{a}-\mathrm{c}$ & $55.5 \mathrm{ab}$ & $3.3 \mathrm{ab}$ & $12.6 \mathrm{ab}$ & $36.7 \mathrm{~cd}$ & $25.7 b c$ & $70.2 \mathrm{c}-\mathrm{g}$ & $100.0 \mathrm{a}$ & $22.5 p$ \\
\hline ISI7 & 72.7 a-f & $54.6 \mathrm{a}-\mathrm{c}$ & $2.9 \mathrm{a}-\mathrm{f}$ & $11.5 \mathrm{a}-\mathrm{d}$ & $38.1 b c$ & $27.0 \mathrm{~b}$ & $70.8 \mathrm{~b}-\mathrm{g}$ & $88.9 a-c$ & $20.0 \mathrm{~s}$ \\
\hline ISI8 & $71.3 \mathrm{c}-\mathrm{g}$ & 51.3b-e & $2.5 \mathrm{e}-\mathrm{g}$ & $8.5 \mathrm{e}-\mathrm{g}$ & $27.0 \mathrm{i}-\mathrm{k}$ & 19.0h-j & $70.5 \mathrm{~b}-\mathrm{g}$ & $100.0 \mathrm{a}$ & $24.5 n$ \\
\hline ISI9 & $71.7 \mathrm{c}-\mathrm{g}$ & $47.8 \mathrm{c}-\mathrm{h}$ & $2.4 \mathrm{fg}$ & $10.3 b-g$ & $31.6 \mathrm{e}-\mathrm{h}$ & $21.1 \mathrm{~d}-\mathrm{h}$ & $67.1 \mathrm{f}-\mathrm{j}$ & $80.9 a-c$ & $32.5 \mathrm{~h}$ \\
\hline ISI10 & $65.7 \mathrm{gh}$ & $54.6 a-c$ & $2.8 \mathrm{~b}-\mathrm{g}$ & $10.8 \mathrm{a}-\mathrm{e}$ & $30.6 f-i$ & $19.9 \mathrm{f}-\mathrm{i}$ & $65.0 \mathrm{~g}-\mathrm{k}$ & $86.7 a-c$ & 25.51 \\
\hline ISI11 & 72.5 b-f & $45.8 \mathrm{~d}-\mathrm{i}$ & $2.9 \mathrm{a}-\mathrm{f}$ & $12.4 \mathrm{ab}$ & $37.7 b c$ & $26.7 b$ & $70.7 b-g$ & $94.4 \mathrm{ab}$ & $19.5 \mathrm{t}$ \\
\hline ISI12 & $76.1 \mathrm{a}-\mathrm{d}$ & $49.0 \mathrm{~b}-\mathrm{g}$ & $3.3 \mathrm{ab}$ & $10.3 b-g$ & $29.1 f-j$ & $21.7 \mathrm{~d}-\mathrm{h}$ & $74.5 \mathrm{a}-\mathrm{d}$ & $100.0 \mathrm{a}$ & 21.0r \\
\hline ISI13 & $72.4 \mathrm{~b}-\mathrm{f}$ & $45.0 \mathrm{e}-\mathrm{i}$ & $2.6 \mathrm{~d}-\mathrm{g}$ & $8.8 \mathrm{~d}-\mathrm{g}$ & $27.0 \mathrm{i}-\mathrm{k}$ & $16.7 \mathrm{jk}$ & $62.0 \mathrm{i}-\mathrm{k}$ & $95.5 \mathrm{ab}$ & $32.0 \mathrm{i}$ \\
\hline ISI14 & $70.2 \mathrm{~d}-\mathrm{g}$ & $44.0 \mathrm{~g}-\mathrm{i}$ & $3.4 \mathrm{a}$ & $9.0 \mathrm{c}-\mathrm{g}$ & $27.3 \mathrm{~h}-\mathrm{k}$ & $16.9 \mathrm{jk}$ & $61.9 \mathrm{jk}$ & $95.8 \mathrm{ab}$ & $30.5 \mathrm{j}$ \\
\hline ISI15 & $62.7 \mathrm{~h}$ & $49.0 \mathrm{~b}-\mathrm{g}$ & $3.4 \mathrm{a}$ & $9.7 b-g$ & $26.1 \mathrm{j}-1$ & $19.4 \mathrm{~g}-\mathrm{j}$ & 74.0a-e & $86.4 \mathrm{a}-\mathrm{c}$ & $33.0 \mathrm{~g}$ \\
\hline ISI16 & $78.8 \mathrm{a}$ & $52.6 a-d$ & $3.1 \mathrm{a}-\mathrm{d}$ & $10.6 b-f$ & $28.7 f-j$ & 21.0d-h & $73.2 \mathrm{a}-\mathrm{f}$ & $92.3 \mathrm{a}-\mathrm{c}$ & $28.0 \mathrm{k}$ \\
\hline ISI17 & 75.9 a-d & $41.9 \mathrm{~h}-\mathrm{j}$ & $2.9 \mathrm{a}-\mathrm{f}$ & $9.4 \mathrm{c}-\mathrm{g}$ & $\begin{array}{c}23.8 \mathrm{k}- \\
\mathrm{m}\end{array}$ & $15.2 \mathrm{k}-\mathrm{m}$ & $63.8 \mathrm{~h}-\mathrm{k}$ & $74.5 \mathrm{c}$ & $41.5 b$ \\
\hline ISI18 & $71.1 \mathrm{c}-\mathrm{g}$ & $36.5 \mathrm{j}$ & $2.5 \mathrm{e}-\mathrm{g}$ & $7.5 \mathrm{~g}$ & 18n.6 & $13.31 \mathrm{~m}$ & $71.3 \mathrm{~b}-\mathrm{g}$ & $100.0 \mathrm{a}$ & $30.5 \mathrm{j}$ \\
\hline ISI19 & 74.3 a-e & $41.3 \mathrm{~h}-\mathrm{j}$ & $3.4 \mathrm{a}$ & $10.1 \mathrm{~b}-\mathrm{g}$ & $26.8 \mathrm{i}-\mathrm{k}$ & $20.5 \mathrm{e}-\mathrm{h}$ & 76.7ab & $100.0 \mathrm{a}$ & 25.51 \\
\hline ISI20 & $71.2 \mathrm{c}-\mathrm{g}$ & $36.3 \mathrm{j}$ & $2.6 \mathrm{~d}-\mathrm{g}$ & $7.7 \mathrm{fg}$ & $21.1 \mathrm{mn}$ & $16.0 \mathrm{kl}$ & $75.8 \mathrm{a}-\mathrm{c}$ & $100.0 \mathrm{a}$ & $22.0 q$ \\
\hline Mean & 72.8 & 48.3 & 2.9 & 10.5 & 31.4 & 21.9 & 69.8 & 92.6 & 28.7 \\
\hline Pop1 & $76.0 \mathrm{a}-\mathrm{d}$ & $55.3 \mathrm{ab}$ & $2.3 \mathbf{g}$ & $10.9 \mathrm{a}-\mathrm{e}$ & $39.4 b c$ & $30.9 a$ & $78.3 \mathrm{a}$ & $85.6 a-c$ & $42.0 \mathrm{a}$ \\
\hline Pop2 & 73.6 a-e & $\begin{array}{c}46.5 \mathrm{~d}-\mathrm{id}- \\
\mathrm{i}\end{array}$ & $2.8 \mathrm{~b}-\mathrm{g}$ & $11.8 \mathrm{a}-\mathrm{c}$ & $27.7 \mathrm{~g}-\mathrm{k}$ & $20.4 \mathrm{f}-\mathrm{h}$ & 73.6a-e & $78.5 b c$ & $41.5 b$ \\
\hline Pop3 & 73.9 a-e & $49.1 \mathrm{~b}-\mathrm{g}$ & $2.7 \mathrm{c}-\mathrm{g}$ & $11.3 \mathrm{a}-\mathrm{e}$ & $32.5 \mathrm{~d}-\mathrm{f}$ & $22.2 \mathrm{~d}-\mathrm{f}$ & $68.3 \mathrm{~d}-\mathrm{i}$ & $100.0 \mathrm{a}$ & $25.0 \mathrm{~m}$ \\
\hline Pop4 & $66.9 \mathrm{f}-\mathrm{h}$ & $48.0 \mathrm{c}-\mathrm{h}$ & $3.1 \mathrm{a}-\mathrm{d}$ & $11.9 \mathrm{a}-\mathrm{c}$ & $35.3 \mathrm{c}-\mathrm{e}$ & $23.5 \mathrm{~cd}$ & $66.6 \mathrm{~g}-\mathrm{j}$ & $90.0 \mathrm{a}-\mathrm{c}$ & $32.0 \mathrm{i}$ \\
\hline Mean & 72.6 & 49.7 & 2.7 & 11.5 & 33.7 & 24.3 & 71.7 & 88.5 & 35.1 \\
\hline Pop5 & $71.1 \mathrm{c}-\mathrm{g}$ & $44.3 \mathrm{f}-\mathrm{i}$ & $2.8 \mathrm{~b}-\mathrm{g}$ & $8.8 \mathrm{~d}-\mathrm{g}$ & $18.7 \mathrm{n}$ & $13.2 \mathrm{~m}$ & $70.5 b-g$ & $94.1 \mathrm{ab}$ & $37.5 f$ \\
\hline $\begin{array}{c}\text { Base } \\
\text { Bulk } \\
\text { (Pop6) } \\
\end{array}$ & 70.3d-g & $40.6 \mathrm{i}$ & $2.8 \mathrm{~b}-\mathrm{g}$ & 8.6d-g & 22.31-n & 17.3i-k & 77.8a & 89.1a-c & 37.5f \\
\hline G. mean & 72.6 & 48.1 & 2.9 & 10.5 & 30.9 & 21.7 & 70.5 & 91.9 & 30.3 \\
\hline
\end{tabular}

ISI1, ISI2, ISI3 = Individual selection number one, two and three, respectively under infested field from the previous 2008/2009 season. G. mean = Grand mean

Means followed by the same letter(s) in the same column are not significantly different. 
Orobanche or free conditions. Actually, the materials grown in free field had better performance than those grown under Orobanche Orobanche. When both materials are evaluated under Orobanche This may be due to:

1.The better performance potential of materials grown in free plots compared to those grown under Orobanche stress.

2.Multiplication under Orobanche stress reduces the potentiality of performance next season. However, one generation of multiplication may not be enough to assure consistent results. Perhaps the situation may differ when more generations of multiplication are practiced (this result is in harmony with Abdalla and Darwish, 1994 and Abdalla et al., 2012).

\section{REFERENCES}

Abdalla M.M.F. (1976). Natural variability and selection in some local and exotic populations of field beans, Vicia faba L. Z. Pflanzenzuchtg., 76: 334-343.

Abdalla M.M.F. and Fischbeck G. (1992). Investigations on faba beans, Vicia faba L. 1Collecting and evaluating 209 landraces. Proc. $5^{\text {th }}$ Conf, Agron., Zagazig, 13-15 Sept. 1:334-344.

Abdalla M.M.F. and Darwish D.S. (1994). Breeding faba bean for Orobanche tolerance at Cairo University. Biology and Management of Orobanche, Proc. $3^{\text {rd }}$ Inter. Workshop on Orobanche and related Striga research 450-454. A.H., Pieterse J.A.C. Verkleij and S.J. ter Borg (eds.). RTI, Amsterdam, Netherlands.

Abdalla M.M.F. and Darwish, D.S. (2008). Investigations on faba beans Vicia faba L. 24- Cairo 4, Cairo 5 and Cairo 25 new varieties tolerant to Orobanche. Egypt. J. Plant Breed., 12 (1): 315-320.
Abdalla M.M.F., Darwish D.S., El-Hady M.M. and El-Emam E.A.A. (2012). Investigations on faba bean, Vicia faba L. 29- Improving yield and its components in two populations through early pedigree selection. Egypt. J. Plant Breed. 16 (4): 1-14.

Abdalla M.M.F., Shafik M.M. and Abd ElWahab M.M.H. (2014). Investigations on faba beans, Vicia faba L. 31. Individual and bulk selection in variety Cairo 4 under Orobanche stress and free field. Egypt. J. Plant Breed. 18 (2): 265-280.

Ashrie A.M.A., Mohamed Eman A.I., Helal A.A., Abdel-Tawab Y.M. and EL-Harty E.H. (2010). Performance of six faba bean genotypes under free and Orobanche soils. Egypt. J. Plant Breed. 14 (2) 189-205.

Bond D.A. (1982). Development and performance of synthetic varieties of Vicia faba L. In:Faba Bean Improvement: 41-51, G. Hawtin and C. Webb (eds.). Martinus Nijhoff, The Netherlands.

Freed R.S.R, Eisensmith S., Goetez D., Reicesky V., Smail W., Wolberg P. (1989). User's Guide to MSTAT-C: A software program for the Design, Management and Analysis of Agronomic Research Experiments Michigan State University, East Lansing, ML., USA.

Gomez A. K. and Gomez A. A. (1984). Statistical Procedures for Agricultural Research ( $2^{\text {nd }}$ ed.). John Wiley and Sons, lnc., New York, USA.

Steel R.G.D., Torrie J.H., Dicky D.A. (1997). Principls and Procedures of Statistics: a biometrical approach. $3^{\text {rd }}$ Ed. McGraw Hill, Inc. Book Co. N.Y, (U.S.A), pp 352-358.

Tewfic H.A. (1956). Developmental stages of seedlings of Orobanche crenata (Forsk.) in relation to its host Vicia faba (Linn.). M.Sc. Thesis Fac. Agric. Ain Shams Univ., Egypt.

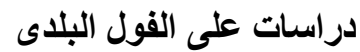

$$
\begin{aligned}
& \text { 34- طرق الاتتخاب ويذور الاصل للصنف قاهرة } 4 \text { من الحقول النظيفه }
\end{aligned}
$$

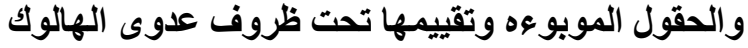

$$
\begin{aligned}
& \text { مجدى محمد شفيق- مظهر محمد فوزى عبد الله ـ مصطفي محمد حسن عبد الوهاب } \\
& \text { قسم المحاصيلـ كلية الزر اعة ـ جامعة القاهرة ـ الجيزة ـ مصر } \\
& \text { ملخص }
\end{aligned}
$$

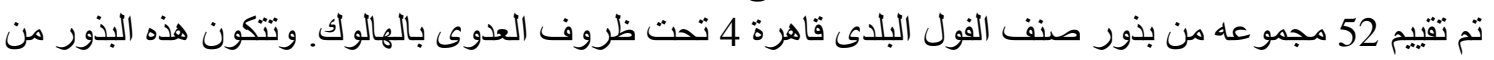

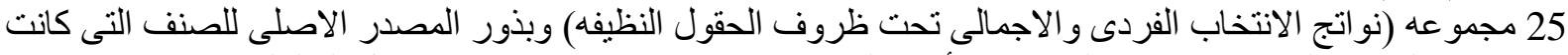

$$
\begin{aligned}
& \text { مخزنه فى الحجره المبرده بالاضافة الى بذور الأخوه التى كانت منزر عاده وتم انتخابها فى حقول الهالوك. الأك. }
\end{aligned}
$$




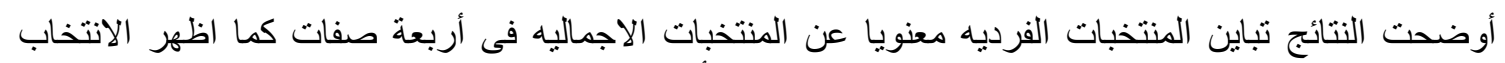

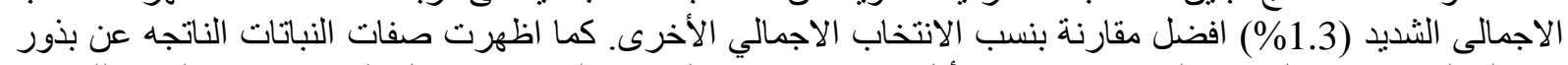

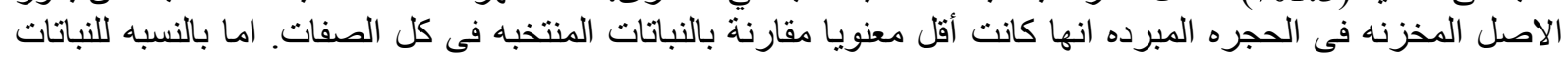

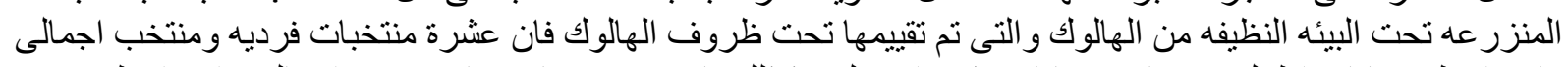

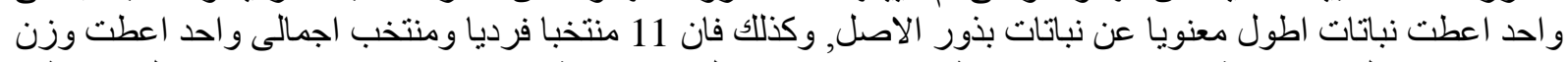

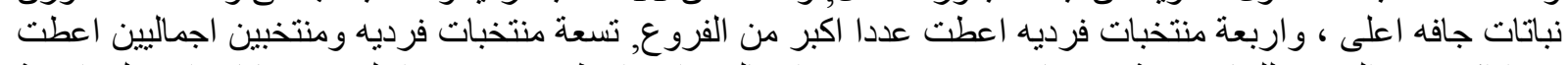

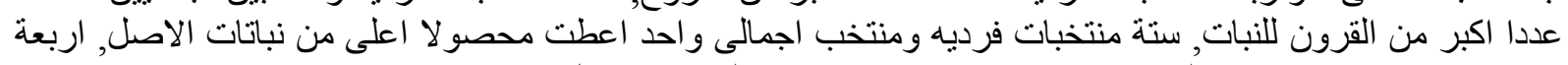

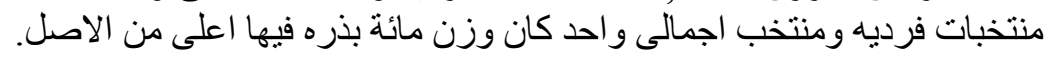

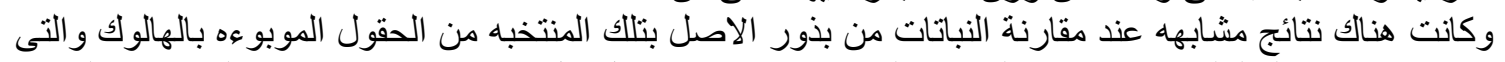

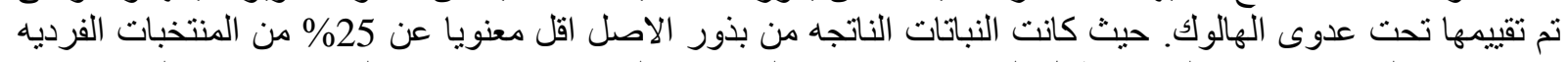

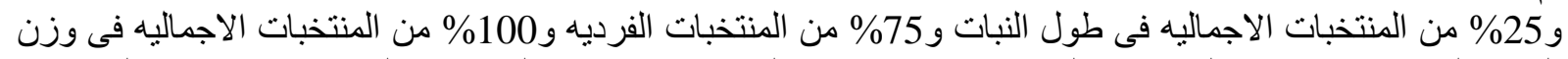

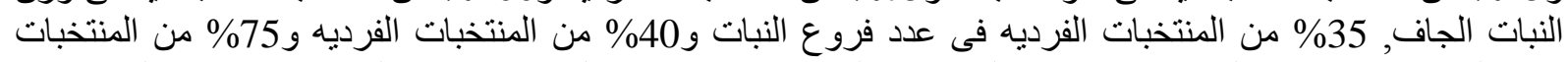

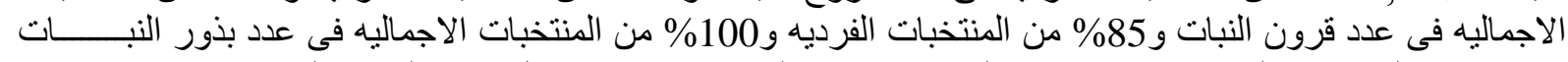

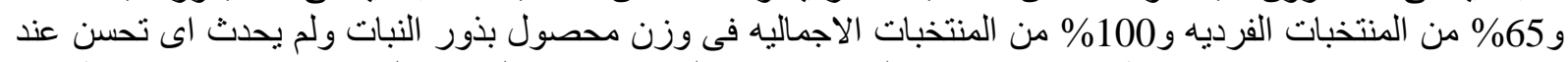

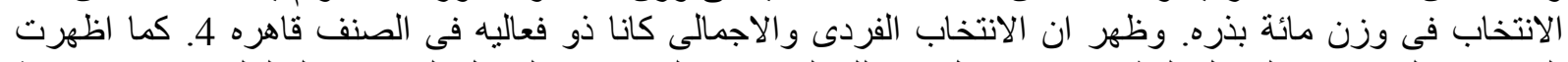

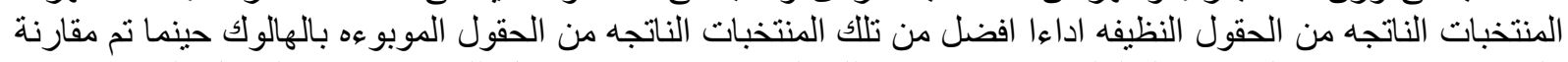

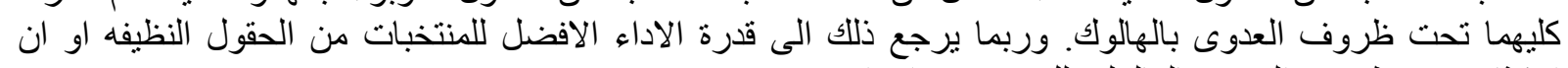

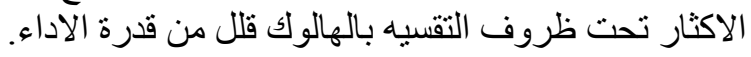

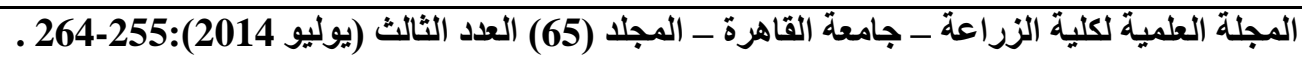

